\title{
Growth Opportunity, Capital Intensity, and Accounting Conservatism: The Moderating Role of Managerial Ownership
}

\section{Nafi'lnayati Zahro}

University of Muria Kudus, Indonesia

ORCID:

Nafi'Inayati Zahro: http://orcid.org/0000-0001-5524-289X

\section{Abstract}

The application of accounting conservatism in presenting and disclosing financial information is important and necessary due to the tendency of management in presenting financial statements with an overstated inclination which can mislead users. The purpose of this research is to examine and analyse the effect of growth opportunity and capital intensity on accounting conservatism and to consider managerial ownership as a moderating variable. The population of the research is the

Corresponding Author: Nafi'Inayati Zahro nafi'.inayati@umk.ac.id

Published: 8 July 2021

Publishing services provided by Knowledge E

(c) Nafi'Inayati Zahro. This article is distributed under the terms of the Creative Commons

Attribution License, which permits unrestricted use and redistribution provided that the original author and source are credited.

Selection and Peer-review under the responsibility of the AICoLiN Conference Committee. manufacturing companies listed on the Indonesia Stock Exchange during the period of 2016-2019. This research uses a purposive sampling method in the selection of the sample based on detailed criteria. This method obtains samples of as many as 53 companies during the period of observation. The research uses moderated regression analysis. The results of this research find that capital intensity has a positive effect on accounting conservatism, but the growth opportunity has influences negatively significant to accounting conservatism. The study also finds that managerial ownership successfully manages to become a moderating variable between growth opportunities and capital intensity on accounting conservatism.

Keywords: conservatism, accounting, growth, capital, managerial

\section{Introduction}

The purpose of financial statements is to provide information regarding the financial position and performance and all changes regarding the financial position, performance and changes in the financial position of a company that provides benefits to users of financial reports for making economic decisions. Financial reports are a source of information on company performance that is prepared based on guidelines for accounting principles, one of which is the principle of accounting conservatism in preparing financial statements. [1] revealed that financial reports that adhere to the principle of accounting 
conservatism are able to prevent information asymmetry which can be done by limiting management in manipulating financial reports. However, accounting conservatism can also cause its own problems because it is based on the theory of [2] about agency theory which shows a conflict of interest between company owners or shareholders (principal) and management as an agent. The principle of conservatism is a principle related to company earnings information, [3] states that the conservatism principle is assumed to be based on future economic uncertainty because conservatism recognizes possible costs or losses but does not immediately recognize profit even though it is likely to occur. Thus, the existence of the principle of accounting conservatism needs to be considered in its application as a careful measure in measuring and recognizing the value of income and profits.

Growth Opprtunity is an important hope desired by company management as an internal party as well as by creditors and investors. High sales growth often increases market expectations of future cash flows so that it will affect accounting conservatism. The growth of the company in the future indicates that the company is able to achieve a high level of profit, the higher the sales growth indicates that the company is more conservative, [4].

High sales growth often increases market expectations of future cash flows so that it will affect conservatism. The company's future growth indicates that the company has reached a high level of profit. The higher the sales growth indicates that the company is getting more conservative.

Based on the theoretical basis and the results of previous research, the following hypotheses can be formulated:

H1: Growth opportunity has a positive effect on accounting conservatism

$\mathrm{H} 2$ : Capital intensity has a positive effect on accounting conservatism

H3: Managerial ownership moderates the relationship between growth opportunity and accounting conservatism

H4: Managerial ownership moderates the relationship between capital intensity and accounting conservatism

\section{Research Method}

The type of research use quantitative research method. The population in this study are all manufacturing companies listed on the Indonesia Stock Exchange (BEI) for the 
2016-2019 period. The sampling technique in this study used a purposive sampling method.

\section{The variables used in this study are as follows:}

\subsection{Accounting Conservatism}

Conservatism is the principle that most influences valuation in accounting, therefore conservatism still has an important role in accounting practice. The calculation of accounting conservatism in this study uses the [5] model, accounting conservatism is measured by looking at the difference between operating profit before depreciation / amortization and operating cash flows divided by total assets.

$$
\text { CONACC }=\frac{(\mathrm{NIO}+\mathrm{DEP}-\mathrm{CFO}) \times(-1)}{\mathrm{TA}}
$$

Information:

CONACC: Accounting conservatism based on accrual calculations

NIO: Operating profit (business) for the year

DEP: Depreciation expense for fixed assets and amortization expense for intangible assets for the current year

CFO: Cash flows from operating activities during the year

TA: Total assets at the end of the period

\subsection{Growth Opportunity}

Growth opportunity is a company opportunity to increase the amount of investment. Management that applies conservative accounting to report quality earnings is characterized by a relatively permanent understatement of earnings and net assets, which is shown through financial reports, which is a positive signal from management to investors, [6]. Growth opportunities can be measured using measurements based on the Market to Book Value of Equity. With the calculation formula as follows:

$$
\text { Market to Book Value of Equity }=\frac{\text { number of outstanding shares } \times \text { closing price }}{\text { Total of equity }}
$$

Sumber: [7] 


\subsection{Capital Intensity}

Capital intensity describes how much the company's capital is in the form of assets to generate company revenue. The higher the capital intensity, the greater the company's income

generated from the company's capital in the form of assets. A high capital intensity ratio

indicates that the company is a capital intensive company.

$$
\text { Capital Intensity }=\frac{\text { total asset }}{\text { total sales }}
$$

Source: [8]

\subsection{Managerial ownership}

In this study, using a moderating variable, namely managerial ownership. Managerial ownership structure is an arrangement of the number of shares owned by management in a company. According to [9], conflicts of interest between managers and shareholders usually also occur in relation to investment decisions made by companies.

In this study, managerial ownership is measured using the following measurements:

$$
\text { MOWN }=\frac{\text { The number of shares owned by comissioners and directors }}{\text { number of shares outstanding }}
$$

Source: [7]

\section{Results and Discussion}

Hypothesis testing in this study was tested using moderated regression analysis with a significance level (alpha) of 5\%, and the following results were obtained:

The test results show that the $R 2$ value is 0.585 . This $R$ square value means that $58.5 \%$ of the stock return variable can be explained by the variable growth opportunity, capital intensity, and managerial ownership. This means that the remaining $41.5 \%$ is explained by other variables outside of this study. From the Anova test or $F$ test, the calculated $F$ value is 15.141 with a significance level of 0.005 ,the regression model can be used in this study. The variables of growth opportunity, capital intensity, and managerial ownership moderation together can influence accounting conservatism. Based on the individual parameter significance test or $t$ test, it shows that the dependent variable growth opportunity has a significance value of 0.148 and a regression coefficient of -0.058 . By 
TABLE 1

\begin{tabular}{l|c|c|c|}
\hline Variabel & Koef.regresi & T & Probabilitas. Sig \\
\hline C & 0,125 & 1,287 & 0,172 \\
\hline X1 & $-0,058$ & 0,150 & 0,148 \\
\hline X2 & 0,292 & 2,969 & 0,004 \\
\hline X1_Z & 0,210 & 2,985 & 0,017 \\
X2_Z & 3,210 & 2,537 & 0,013 \\
\hline R square $\left(R^{2}\right)=0,586$ & & & \\
\hline F statistic = 15,141 & & \\
Probabilitas F Statistic $=0,005$ & & \\
\end{tabular}

using a 5\% alpha level, the value of growth opportunity is greater than the significance level, namely $0.148>0.05$. This shows that there is no influence of growth opportunity on accounting conservatism, this is in line with the research of [10] which states that growth opportunities have no effect on accounting conservatism, but it is not in line with the research results of [11] and the research of [12] which has proven that growth opportunity has succeeded in influencing accounting conservatism. However, when the managerial ownership variable is included as an intermediary or the interaction of the relationship between growth opportunity and accounting conservatism shows a significance value of 0.017 which is smaller than 0.05 , in the sense that managerial ownership is able to positively moderate the relationship between growth opportunity and accounting conservatism, $\mathrm{H} 3$ is successfully accepted. Meanwhile, the $\mathrm{H} 2$ test results show that the capital intensity variable has a significance value of 0.004 and a regression coefficient of 0.292 . This proves that the second hypothesis is accepted which indicates that capital intensity has a positive influence on accounting conservatism. Likewise, when the managerial ownership variable is included as a moderation between capital intensity and accounting conservatism, it shows a significance value of 0.013 which is smaller than the 0.05 significance level, which proves that managerial ownership is able to moderate the relationship between capital intensity and accounting conservatism.

\section{Conclusion}

This study aims to examine the effect of growth opportunity and capital intensity on accounting conservatism, and include managerial ownership as a moderating variable. Based on the results of the study, it shows that capital intensity has a positive effect on accounting conservatism, which is indicated by a significance value smaller than 0.05 . However, growth opportunity did not succeed in influencing accounting conservatism. Not all managers apply the principle of conservatism by minimizing profits to meet 
investment needs. The opportunity to grow a company requires funds, most of which come from external parties so that the company does not reduce profits, [7]. This study also succeeded in proving that the managerial ownership variable succeeded in becoming a moderating variable capable of interacting the relationship between growth opportunity and capital intensity with accounting conservatism, as evidenced by the significance value of both below 0.05 .

\section{Suggestion}

a. For further researchers, it can take a broader scope not only in the manufacturing sector but can be expanded to other sectors such as the service sector listed on the Indonesia Stock Exchange.

b. For further researchers, they can add independent variables related to accounting conservatism, such as company size variables. The larger the size of the company will pay a greater political cost, so that managers will choose to reduce profits to be more conservative, [13].

\section{References}

[1] LaFond R, Watts RL. The information role of conservatism. The Accounting Review. 2008;83:447-478.

[2] Jensen MC, Meckling WH. Theory of The Firm Management Behavior, Agency, and Ownership Structure. Journal of Financial Economics. 1976;3:305-360.

[3] Tazkia H, Sulastiningsih S. Pengaruh growth opportunity, financial distress, ceo retirement terhadap konservatisme akuntansi. Jurnal Kajian Bisnis. 2020;28(1):13-34.

[4] Andreas, DKK. Konservatisma Akuntansi di Indonesia. Jurnal Ekonomi dan Bisnis. 2017;20(1).

[5] Givoly D, Hayn C. The changing time-series properties of earnings, cash flows and accruals: has financial reporting become more conservative?. Journal of Accounting and Economics. 2000;29:287-320.

[6] Fala, DAS. Pengaruh konservatisma akuntansi terhadap penilaian ekuitas perusahaan dimoderasi oleh good corporate governance. Simposium Nasional Akuntansi X. Makassar. Indonesia; 2010.26-28 Juli.

[7] Wulansari CA, Ridwan A. Pengaruh kepemilikan, kontrak hutang dan kesempatan tumbuh pada konservatisme akuntansi. Jurnal IImu \& Riset Akuntansi. 2014;3(8). 
[8] Ross SA, Westerfield RW, Jordan BD. Fundamentals of Corporate Finance. $9^{\text {th }}$ ed. Boston: McGraw; 2010.

[9] Tandelilin E, Wilberforce T. "Can debt and dividend policies substitute insider ownership in controlling equity agency conflict?". Gadjah Mada International Journal of Business. 2002;4:31-43

[10] Septian A, Yane DA. Pengaruh kepemilikan manajerial, ukuran manajerial, debt covenant dan growth opportunities terhadap konservatisme akuntansi. E-proceeding of Management. 2014;1(3).

[11] Alfian A, Sabeni A. Analisis faktor-faktor yang berpengaruh terhadap pemilihan konservatisme akuntansi. Diponegoro Journal of Accounting. 2013;2,3:1-10

[12] Tazkia H, Sulastiningsih S. Pengaruh growth opportunity, financial distress, CEO retirement terhadap konservatisme akuntansi. Jurnal Kajian Bisnis. 2020;28(1):13-34.

[13] Sari C, Desi A. Konservatisme perusahaan di Indonesia dan faktor-faktor yang mempengaruhinya. Makalah Simposium Nasional Akuntansi XI. Pontianak;2009 